\title{
Salmonella Contamination Associated with Bacterial Soft Rot of Fresh Fruits and Vegetables in the Marketplace
}

\author{
J. M. Wells and J. E. Butterfield, U.S. Department of Agriculture, ARS, Eastern Regional Research Center, 600 E. \\ Mermaid Lane, Wyndmoor, PA 19038
}

\begin{abstract}
Wells, J. M., and Butterfield, J. E. 1997. Salmonella contamination associated with bacterial soft rot of fresh fruits and vegetables in the marketplace. Plant Dis. 81:867-872.

Wash water from $66 \%$ of 401 samples of fresh fruits and vegetables collected in the marketplace and affected by bacterial soft rot were positive for suspected strains of Salmonella, i.e., black, hydrogen sulfide-positive colonies on Salmonella-Shigella agar incubated for $24 \mathrm{~h}$ at $37^{\circ} \mathrm{C}$. By comparison, $30 \%$ of 402 healthy samples were positive. Incidence of suspected Salmonella in broth enrichment cultures was 59\% in 533 soft rotted samples and $33 \%$ in 781 healthy samples. Thirty percent of 166 representative strains of suspected Salmonella, selected at random from 20 different commodities, were confirmed to be Salmonella by physiological and serological tests. Adjusting incidence values accordingly, Salmonella contamination was potentially present in at least 18 to $20 \%$ of soft rotted samples and in 9 to $10 \%$ of healthy samples. Wash water from 120 paired healthy and soft rotted fruits and vegetables contained an average of $1.0 \times 10^{5}$ and $3.7 \times 10^{6} \mathrm{CFU} / \mathrm{ml}$, respectively, of suspected Salmonella-a ratio of 1:37. Average concentrations of suspected Salmonella in enrichment cultures of healthy and soft rotted samples were $7.5 \times 10^{7}$ and $2.7 \times 10^{9} \mathrm{CFU} / \mathrm{ml}$, respectively, also in the ratio of 1:37. Fresh potato, carrot, and pepper disks coinoculated with the soft rot bacterium Erwinia carotovora and with Salmonella typhimurium, and incubated for up to $72 \mathrm{~h}$ at room temperature, contained approximately 10 times the concentration of S. typhimurium as did disks inoculated with Salmonella alone. Disks coinoculated with Pseudomonas viridiflava and S. typhimurium contained approximately three times the Salmonella populations as disks inoculated with Salmonella alone.
\end{abstract}

Contamination of horticultural products by fecal coliforms is well documented and is recognized as a potential public health problem $(13,14)$. Occasional reports of multistate outbreaks of salmonellosis in the United States associated with contaminated fresh fruits and vegetables have coincided with increased consumption of fresh produce in recent years due to changing consumer preferences, greater selections, wider distribution, and year-round availability (16). Recent outbreaks have been associated with Salmonella chester and $S$. poona on cantaloupes from the lower Rio Grande area in Texas (10), with $S$. javania and $S$. montevideo on tomatoes from North and South Carolina $(9,27)$ and with Salmonella sp. on alfalfa sprouts (24). In foreign countries, as well as in the United States,

Corresponding author: J. M. Wells

E-mail: jwells@ arserrc.gov

Mention of brand or firm names does not constitute an endorsement by the United States Department of Agriculture over others of a similar nature not mentioned.

Accepted for publication 24 April 1997

Publication no. D-1997-0527-07R

This article is in the public domain and not copyrightable. It may be freely reprinted with customary crediting of the source. The American Phytopathological Society, 1997.
Salmonella outbreaks have been associated with consumption of celery, watercress, watermelon, lettuce, cabbage, and raw salad vegetables $(13,14)$. As an indicator of enteric bacteria, Salmonella is commonly isolated from horticultural crops or from wash waters. In Italy, Ercolani found Salmonella in wash water from $68 \%$ of lettuce and $72 \%$ of fennel samples tested (8). In the United States, Rude et al. cultured Salmonella from 4 of 50 vegetables sampled (22). In Spain, Garcia-Villanova-Ruiz et al. detected Salmonella in $7.5 \%$ of market vegetables sampled (12), and incidence on various vegetable commodities has been reported in England (19), Egypt (23), Iraq (1), and Italy (11).

Although research and epidemiological data outline broad features of a problem, there are many obscure details relating to the causes of Salmonella contamination. Also unclear is the relationship between the incidence of indicator bacteria and actual clinical cases of salmonellosis, and specific factors associated with produce marketing and food preparation that aggravate the problem. The present research describes one possible source of contamination: the association between Salmonella and bacterial soft rot, one of the most common postharvest diseases of horticultural crops.

Bacterial soft rot is a leading cause of postharvest losses of potatoes (4), tomatoes
(6), peppers (7), lettuce (5), and other fresh fruits and vegetables in the marketplace. It is caused by a group of plant pathogens, harmless to humans, that includes Erwinia carotovora (subsp. carotovora and atroseptica), pectolytic Pseudomonas fluorescens ( $P$. marginalis), and $P$. viridiflava (18). Pectolytic breakdown of affected tissues results in softening, liquefaction, and exudates that can spread bacteria over commodities in bulk storage or display, contaminate food-handling equipment, and protect bacteria from the environment $(25,26)$.

E. carotovora, the most common member of the soft rotting bacterial complex, is a member of the Enterobacteriaceae, which includes Salmonella and other enteric bacteria of importance to public health. They can be soilborne, and they share ecological niches such as soft rotted plant tissues where liquefaction provides a rich bacteriological medium. Salmonella and Erwinia can be taxonomically separated by several key biochemical properties, but the most useful and distinguishing traits are their optimum growth temperatures and pathogenicity (3). This report specifically examines the association and interaction of the two in the context of bacterial soft rot disease of fresh fruits and vegetables.

\section{MATERIALS AND METHODS}

Collection of samples in the marketplace. Samples of 48 different fruits and vegetables, listed in Table 1 , were collected in local supermarkets in Somerset and Middlesex counties, New Jersey, on a periodic basis between 1992 and 1995 . Approximately twice a month, healthy specimens were randomly selected from retail displays. Healthy samples were those free of blemishes, wounds, or decayed areas. Soft rotted samples, as they were available, were obtained from materials culled by store personnel and from displays. Soft rotted samples were those with water-soaked or macerated lesions, with or without bacterial exudation, characteristic of early bacterial soft rot development (25). When matched samples were obtained, the healthy sample was collected from the vicinity of the soft rotted sample. Samples with advanced bacterial soft rot or collapsed tissues, or suspected of mixed bacterialfungal infections, were not collected.

Preparation of washes and isolation protocol. Depending on the specific com- 
modity, 10- to 600-g samples were washed with agitation for $30 \mathrm{~min}$ in $500 \mathrm{ml}$ of sterile water. Healthy samples usually constituted an entire bunch of leafy herbs or greens (100 to $450 \mathrm{~g}$ ), half to whole heads of lettuce and umbellifers depending on size (200 to $500 \mathrm{~g}$ ), one or up to six of the larger fruits and vegetables (edible portions only, 300 to $600 \mathrm{~g}$ ), and 6 to 18 of the smaller commodities such as snap beans, mushrooms, radishes, and cherry tomatoes (200 to $450 \mathrm{~g}$ ). Soft rotted samples were washed as single whole items (200 to 600 $\mathrm{g}$ ), excised portions (10 to $60 \mathrm{~g}$ ), or in the case of leafy vegetables, as infected leaves or portions of leaves (10 to $100 \mathrm{~g}$ ). When paired samples were tested, the soft rotted portion of a sample was excised and tested as a subsample against the remaining healthy portion.

Samples were tested for possible (i.e., suspected) Salmonella by a modification of the method of Poelma et al. (21) designed (i) to process a large number of samples, (ii) to compare healthy and diseased samples, and (iii) as a preliminary screen for lactose-negative $\mathrm{H}_{2} \mathrm{~S}^{+}$strains, a category that generally encompasses most Salmonella strains except for $S$. paratyphi A and some strains of $S$. choleraesuis (3). Wash water $(1 \mathrm{ml})$ was diluted 10 -fold in selenite cystine enrichment broth (Difco Laboratories, Detroit, MI) and incubated at $37^{\circ} \mathrm{C}$ for $24 \mathrm{~h}$, and $0.1 \mathrm{ml}$ was surface-streaked on Salmonella-Shigella (SS) agar (Difco) by the technique described by Krieg (17) in 60-mm petri plates. In addition, for comparative purposes, $0.1 \mathrm{ml}$ of wash water was streaked directly on SS agar without enrichment. SS plates were incubated at $37^{\circ} \mathrm{C}$ and examined at 24 and $48 \mathrm{~h}$ for black or black-centered (i.e., $\mathrm{H}_{2} \mathrm{~S}^{+}$) colonies.

Sixty field samples were used for a comparison of the modified method just

Table 1. Percent healthy and soft rotted fruits and vegetables positive for black, hydrogen sulfide-positive colonies (suspected Salmonella) in wash and in enrichment broth samples

\begin{tabular}{|c|c|c|c|c|c|c|c|c|}
\hline \multirow[b]{3}{*}{ Commodity } & \multicolumn{4}{|c|}{ Healthy samples ${ }^{a}$} & \multicolumn{4}{|c|}{ Soft rotted samples ${ }^{a}$} \\
\hline & \multicolumn{2}{|c|}{ Wash $^{\text {b }}$} & \multicolumn{2}{|c|}{ Enriched $^{\mathrm{c}}$} & \multicolumn{2}{|c|}{ Wash $^{\mathbf{b}}$} & \multicolumn{2}{|c|}{ Enriched $^{c}$} \\
\hline & Samples (no.) & Positive (\%) & Samples (no.) & Positive (\%) & Samples (no.) & Positive (\%) & Samples (no.) & Positive (\%) \\
\hline Alfalfa sprouts & 5 & 100 & 5 & 100 & 7 & 100 & 7 & 86 \\
\hline Arrugula & 10 & 40 & 10 & 20 & 11 & 82 & 11 & 100 \\
\hline Basil & 8 & 25 & 8 & 25 & 11 & 55 & 11 & 46 \\
\hline Beans, snap & 5 & 20 & 20 & 50 & 5 & 80 & 8 & 100 \\
\hline Bean sprouts & 6 & 100 & 6 & 83 & 6 & 100 & 6 & 83 \\
\hline Beet, greens & 7 & 14 & 10 & 10 & 9 & 78 & 13 & 62 \\
\hline Broccoli & 8 & 12 & 8 & 0 & 7 & 71 & 7 & 86 \\
\hline Broccoli, rabe & 10 & 40 & 10 & 30 & 10 & 50 & 11 & 64 \\
\hline Cabbage & 10 & 20 & 10 & 20 & 9 & 56 & 10 & 30 \\
\hline Calabaza & 11 & 54 & 11 & 45 & 9 & 78 & 9 & 67 \\
\hline Cantaloupe & 6 & 67 & 17 & 47 & 7 & 57 & 8 & 87 \\
\hline Carrot & 10 & 40 & 13 & 46 & 9 & 67 & 11 & 45 \\
\hline Cauliflower & 8 & 12 & 16 & 12 & 8 & 50 & 14 & 36 \\
\hline Celery & 5 & 0 & 42 & 24 & 7 & 43 & 10 & 30 \\
\hline Chicory & 11 & 27 & 11 & 0 & 10 & 60 & 10 & 50 \\
\hline Cilantro & 10 & 10 & 10 & 30 & 11 & 91 & 11 & 64 \\
\hline Collard greens & 10 & 30 & 10 & 30 & 9 & 89 & 9 & 78 \\
\hline Cucumber & 11 & 55 & 21 & 67 & 11 & 91 & 19 & 90 \\
\hline Dill & 8 & 37 & 8 & 50 & 8 & 63 & 8 & 38 \\
\hline Escarole & 8 & 50 & 10 & 20 & 7 & 86 & 8 & 87 \\
\hline Fennel & 12 & 25 & 12 & 33 & 10 & 60 & 10 & 30 \\
\hline Kale & 10 & 10 & 10 & 20 & 8 & 88 & 8 & 75 \\
\hline Lettuce, iceberg & 7 & 0 & 24 & 8 & 7 & 0 & 21 & 10 \\
\hline Lettuce ${ }^{\text {d, leaf }}$ & 14 & 0 & 53 & 19 & 17 & 47 & 17 & 41 \\
\hline Mushroom & 6 & 0 & 11 & 18 & 6 & 33 & 6 & 50 \\
\hline Onion, dry & 11 & 0 & 11 & 9 & 9 & 33 & 9 & 33 \\
\hline Onion, green & 5 & 60 & 15 & 20 & 8 & 50 & 8 & 25 \\
\hline Parsley & 10 & 20 & 10 & 20 & 9 & 33 & 9 & 78 \\
\hline Parsnip & 8 & 50 & 8 & 25 & 8 & 50 & 8 & 37 \\
\hline Pepper, bell type & 18 & 39 & 66 & 35 & 18 & 72 & 58 & 66 \\
\hline Pepper, cubanelle & 8 & 25 & 15 & 27 & 7 & 86 & 9 & 89 \\
\hline Pepper, jalapeño & 10 & 20 & 10 & 50 & 9 & 89 & 9 & 89 \\
\hline Pepper, long hot & 10 & 30 & 10 & 20 & 8 & 25 & 8 & 37 \\
\hline Potato $^{\mathrm{e}}$ & 11 & 91 & 13 & 100 & 9 & 100 & 10 & 100 \\
\hline Radish & 9 & 0 & 10 & 30 & 10 & 70 & 10 & 70 \\
\hline Spinach & 19 & 16 & 58 & 26 & 19 & 90 & 33 & 76 \\
\hline $\mathrm{Squash}^{\mathrm{f}}$ & 7 & 14 & 18 & 61 & 6 & 83 & 7 & 86 \\
\hline Swiss chard & 7 & 43 & 10 & 20 & 8 & 63 & 10 & 90 \\
\hline Tomato & 11 & 55 & 83 & 40 & 11 & 64 & 37 & 41 \\
\hline Tomato, cherry & 7 & 14 & 15 & 47 & 6 & 17 & 7 & 29 \\
\hline Tomato, plum & 6 & 0 & 34 & 41 & 8 & 12 & 9 & 33 \\
\hline Turnip & 10 & 20 & 10 & 10 & 8 & 75 & 8 & 50 \\
\hline Vegetables, mixed & 8 & 38 & 8 & 50 & 12 & 75 & 12 & 67 \\
\hline Watercress & 11 & 27 & 11 & 45 & 9 & 89 & 9 & 33 \\
\hline Totals $^{\mathrm{g}}$ & 402 & 30.3 & 781 & 32.9 & 401 & 65.8 & 533 & 59.3 \\
\hline
\end{tabular}

${ }^{a}$ Approximately 10- to 600-g portions of healthy or soft rotted tissues, depending on the commodity, washed in $500 \mathrm{ml}$ of water for $30 \mathrm{~min}$.

${ }^{\mathrm{b}}$ Wash plated directly on Salmonella-Shigella (SS) agar and incubated for $24 \mathrm{~h}$ at $37^{\circ} \mathrm{C}$.

${ }^{\mathrm{c}}$ One $\mathrm{ml}$ of wash enriched in selenite cystine broth for $24 \mathrm{~h}$ at $37^{\circ} \mathrm{C}$, then plated on SS agar and incubated for $24 \mathrm{~h}$ at $37^{\circ} \mathrm{C}$.

${ }^{\mathrm{d}}$ Including Romaine lettuce.

e Data combined for round red, round white, and russet potatoes.

f Data combined for yellow and zucchini squash.

$\mathrm{g}$ Totals and final averages based on data for aggregated samples. 
described with the standard isolation protocol of enrichment in selenite cystine and in tetrathionate broth, and streaking on Hektoen Enteric (HE), xylose lysine desoxycholate (XLD), and SS agars (Difco) (21). In addition, 42 different pure cultures of bacteria were tested on the three agar media to verify that the soft rotting erwinias and pseudomonads would not grow or produce black or black-centered colonies at $37^{\circ} \mathrm{C}$, and that Salmonella would produce black colonies and could be readily distinguished on SS agar. Bacteria included 12 authenticated strains of Salmonella ( $S$. sp. serotype anatum, S. arizonae, $S$. sp. serotype dublin, $S$. enteritidis and $S$. typhimurium); 3 strains each of pectolytic $P$. fluorescens and $P$. viridiflava; 2 strains of $P$. aeruginosa; and a group of Enterobacteriaceae that included 5 strains of Erwinia carotovora (subsp. carotovora, atroseptica, and wasabiae), 3 strains of Pantoea (formerly Enterobacter) agglomerans, 2 strains each of Enterobacter aerogenes, E. cloaca, E. dissolvens, and E. sakazakii, 2 strains of Escherichia coli, 3 strains of Yersinia enterocolitica, and 1 strain each of Proteus vulgaris, Klebsiella pneumoniae, and Serratia marcescens.

Differences in the incidence and concentration of hydrogen sulfide-positive colonies on healthy and soft rotted tissues were statistically confirmed by $t$ test on Statpro statistical software (Wadworth Professional Software, Inc., Boston, MA).

Confirmation testing of suspected strains of Salmonella. A collection of 166 bacteria from well-isolated black or blackcentered colonies on SS agar, drawn from samples of 20 different commodities, were transferred, single-colony cloned, and maintained at $4^{\circ} \mathrm{C}$ on Pseudomonas Agar $\mathrm{F}$ (PAF, Difco), a medium we found satisfactory as a general-purpose agar for storage of bacterial cultures. Within 2 months of isolation, strains were subcultured, transferred to urea agar tubes, and incubated at $37^{\circ} \mathrm{C}$ for 6 to $18 \mathrm{~h}$. Urease-negative strains were then grown in triple sugar iron (TSI) and lysine iron agar (LIA) slants at $37^{\circ} \mathrm{C}$ for $24 \mathrm{~h}$. Tubes were incubated an additional $24 \mathrm{~h}$ if reactions were negative or borderline. Positive reactions on TSI tubes, for the $\mathrm{H}_{2} \mathrm{~S}^{+}$strains we selected, consisted of red (alkaline) slants, yellow (acid) butts with black streaks $\left(\mathrm{H}_{2} \mathrm{~S}\right.$ reactions), with or without gas production. Positive reactions on LIA consisted of purple slants and butts (alkaline) with or without $\mathrm{H}_{2} \mathrm{~S}$ within $48 \mathrm{~h}$. Strains positive in the TSA/LIA slants were then tested on Roche Enterotube II (Roche Diagnostic Systems, Montclair, NJ) for the indole and Voges-Proskauer reactions, and for additional confirmation of Salmonella by the Enterotube II computer coding and identification system. The confirmation procedure was tested on four of the authenticated strains of Salmonella and on other test species as negative controls. Suspected strains testing positive were considered presumptive Salmonella and then tested serologically.

Serological agglutination tests with Salmonella $\mathrm{O}$ antiserum Poly A-1 and Vi (Difco) were performed according to manufacturer's directions on strains of presumptive Salmonella taken from growth in TSI tubes. Those not reacting with the antiserum were tested with Salmonella $\mathrm{O}$ antiserum Poly C. Strains negative to Poly $\mathrm{C}$ were then tested with antiserum Poly D, and so on through antiserum Poly G. Strains reacting with any of the Salmonella antisera were considered positive. Strains with weak agglutination reactions were retested with the same antiserum for confirmation and then tested with the remaining antisera.

Inoculation of tissue disks with Salmonella and soft rot bacteria. Disks 12 $\mathrm{mm}$ in diameter and 3 to $4 \mathrm{~mm}$ thick were aseptically cut from potato, carrot, or pepper tissues. Three randomly selected disks were placed in $60-\mathrm{mm}$ petri plates and inoculated on cut surfaces with $10 \mu \mathrm{l}$ of a bacterial suspension. Suspensions were prepared from loopfuls of 24- to 48-h cultures grown on PAF agar at $21^{\circ} \mathrm{C}$, washed once, and adjusted to approximately $5 \times$ $10^{8} \mathrm{CFU} / \mathrm{ml}$ by optical density measurements at $590 \mathrm{~nm}$. Disks were inoculated with S. typhimurium (ATCC 14028), E. carotovora strain E24 (obtained from $\mathrm{H}$. Moline, USDA, Beltsville, MD), or $P$. viridiflava strain 312 (obtained from C.-H. Liao, USDA, Philadelphia, PA), or with a mixture of Salmonella and E. carotovora or Salmonella and $P$. viridiflava. Uninoculated control disks were included. Inoculated disks were incubated at $34^{\circ} \mathrm{C}$ for up to $72 \mathrm{~h}$ and sampled at $0,16,24,48$, and $72 \mathrm{~h}$. At each sampling, three disks per bacterial treatment were agitated in $30 \mathrm{ml}$ of sterile water for $10 \mathrm{~min}$, and $10 \mu \mathrm{l}$ was serially diluted to eight logs replicated twice. Dilutions were surface-streaked on SS and on PAF agar $(0.1 \mathrm{ml}$ spread on 60 -

Table 2. Concentration of black, hydrogen sulfide-positive colonies (suspected Salmonella) on Salmonella-Shigella (SS) agar streaked with wash water or enrichment broth from matched samples of healthy and soft rotted fruits and vegetables ${ }^{\mathrm{a}}$

\begin{tabular}{|c|c|c|c|c|c|}
\hline \multirow[b]{2}{*}{ Commodity } & \multirow[b]{2}{*}{$\begin{array}{l}\text { Paired } \\
\text { samples }\end{array}$} & \multicolumn{2}{|c|}{$\begin{array}{l}\text { Black colonies per } \mathrm{ml} \text { of } \\
\text { wash water }\end{array}$} & \multicolumn{2}{|c|}{$\begin{array}{l}\text { Black colonies per ml of } \\
\text { enrichment broth }\end{array}$} \\
\hline & & $\begin{array}{l}\text { Healthy } \\
\text { tissues }\end{array}$ & $\begin{array}{l}\text { Soft rotted } \\
\text { tissues }\end{array}$ & $\begin{array}{l}\text { Healthy } \\
\text { tissues }\end{array}$ & $\begin{array}{l}\text { Soft rotted } \\
\text { tissues }\end{array}$ \\
\hline Basil & 1 & 0 & 0 & 0 & 0 \\
\hline Beans, snap & 3 & 0 & $3.4 \times 10^{6}$ & $5.0 \times 10^{7}$ & $1.0 \times 10^{8}$ \\
\hline Beet, greens & 2 & 0 & $2.0 \times 10^{5}$ & 0 & $1.2 \times 10^{8}$ \\
\hline Broccoli, rabe & 3 & $1.5 \times 10^{4}$ & $5.0 \times 10^{4}$ & $8.5 \times 10^{6}$ & $1.6 \times 10^{6}$ \\
\hline Cabbage & 1 & 0 & 0 & 0 & 0 \\
\hline Cantaloupe & 2 & $1.5 \times 10^{5}$ & $5.0 \times 10^{3}$ & $5.0 \times 10^{5}$ & $4.0 \times 10^{6}$ \\
\hline Carrot & 4 & $1.5 \times 10^{5}$ & $8.9 \times 10^{6}$ & $5.0 \times 10^{5}$ & $5.0 \times 10^{7}$ \\
\hline Cauliflower & 6 & $5.0 \times 10^{4}$ & $8.3 \times 10^{6}$ & $8.0 \times 10^{7}$ & $4.6 \times 10^{9}$ \\
\hline Celery & 5 & 0 & $1.0 \times 10^{5}$ & 0 & $1.0 \times 10^{8}$ \\
\hline Cilantro & 1 & 0 & $1.0 \times 10^{5}$ & 0 & $7.5 \times 10^{8}$ \\
\hline Cucumber & 10 & $2.0 \times 10^{5}$ & $8.9 \times 10^{6}$ & $3.6 \times 10^{9}$ & $7.8 \times 10^{9}$ \\
\hline Dill & 1 & 0 & $1.0 \times 10^{5}$ & 0 & 0 \\
\hline Fennel & 1 & 0 & 0 & $5.0 \times 10^{6}$ & 0 \\
\hline Kale & 1 & 0 & 0 & 0 & $5.0 \times 10^{8}$ \\
\hline Lettuce, iceberg & 5 & 0 & 0 & 0 & 0 \\
\hline Lettuce, Romaine & 3 & 0 & 0 & 0 & $2.5 \times 10^{7}$ \\
\hline Mushroom & 6 & 0 & $1.7 \times 10^{6}$ & $1.6 \times 10^{7}$ & $1.0 \times 10^{6}$ \\
\hline Onion, green & 1 & 0 & 0 & 0 & 0 \\
\hline Parsley & 5 & 0 & 0 & 0 & $3.7 \times 10^{7}$ \\
\hline Pepper, bell type & 13 & $5.0 \times 10^{5}$ & $9.1 \times 10^{6}$ & $2.4 \times 10^{9}$ & $8.9 \times 10^{9}$ \\
\hline Pepper, cubanelle & 3 & 0 & $4.5 \times 10^{5}$ & $5.0 \times 10^{8}$ & $2.6 \times 10^{9}$ \\
\hline Pepper, long hot & 1 & 0 & 0 & 0 & $5.0 \times 10^{7}$ \\
\hline Potato, round red & 1 & $4.0 \times 10^{5}$ & $5.0 \times 10^{7}$ & $5.0 \times 10^{7}$ & $4.5 \times 10^{7}$ \\
\hline Potato, round white & 3 & $5.0 \times 10^{4}$ & $1.4 \times 10^{7}$ & $2.5 \times 10^{8}$ & $4.2 \times 10^{9}$ \\
\hline Potato, russet & 2 & $1.3 \times 10^{5}$ & $3.8 \times 10^{5}$ & $7.5 \times 10^{9}$ & $1.3 \times 10^{9}$ \\
\hline Radish & 4 & 0 & $1.0 \times 10^{5}$ & $2.5 \times 10^{6}$ & $7.5 \times 10^{7}$ \\
\hline Spinach & 15 & 0 & $3.0 \times 10^{5}$ & $1.7 \times 10^{7}$ & $8.6 \times 10^{8}$ \\
\hline Squash, yellow & 2 & 0 & $2.5 \times 10^{5}$ & 0 & $1.3 \times 10^{9}$ \\
\hline Squash, zucchini & 3 & 0 & $3.0 \times 10^{5}$ & $2.3 \times 10^{8}$ & $7.5 \times 10^{8}$ \\
\hline Tomato & 7 & $2.5 \times 10^{5}$ & $1.5 \times 10^{6}$ & $6.0 \times 10^{7}$ & $5.0 \times 10^{8}$ \\
\hline Tomato, plum & 3 & 0 & $1.6 \times 10^{6}$ & 0 & $2.5 \times 10^{9}$ \\
\hline Watercress & 2 & 0 & $5.0 \times 10^{4}$ & 0 & $2.5 \times 10^{7}$ \\
\hline \multicolumn{2}{|c|}{ Average of 120 samples } & $1.0 \times 10^{5}$ & $3.7 \times 10^{6}$ & $7.5 \times 10^{7}$ & $2.7 \times 10^{9}$ \\
\hline \multicolumn{2}{|c|}{ Ratio healthy:soft rot } & \multicolumn{2}{|c|}{$1: 37$} & \multicolumn{2}{|c|}{$1: 37.3$} \\
\hline
\end{tabular}

a Diseased portion of sample (10 to $60 \mathrm{~g}$ ) separated and assayed as a paired subsample with the healthy portion (200 to $600 \mathrm{~g}$ ).

b Samples agitated for $30 \mathrm{~min}$ in $500 \mathrm{ml}$ of sterile water. One $\mathrm{ml}$ wash diluted 10 -fold, plated directly on SS agar, then incubated $24 \mathrm{~h}$ at $37^{\circ} \mathrm{C}$.

${ }^{\mathrm{c}}$ One $\mathrm{ml}$ of wash water diluted 10 -fold in selenite broth, incubated $24 \mathrm{~h}$ at $37^{\circ} \mathrm{C}$, then plated on SS agar and incubated $24 \mathrm{~h}$ at $37^{\circ} \mathrm{C}$. 
$\mathrm{mm}$ plates), and incubated for 24 to $48 \mathrm{~h}$ at 37 and $21^{\circ} \mathrm{C}$, respectively, and colonies were counted. On SS agar at $37^{\circ} \mathrm{C}$, Salmonella appeared as black colonies after $24 \mathrm{~h}$, and Erwinia and Pseudomonas did not grow. On PAF agar at $25^{\circ} \mathrm{C}$, Salmonella could be distinguished from Pseudomonas by the absence of fluorescent pigments, and from Erwinia by colony size and texture. Calculations of viable cells, or CFU, per milliliter were based on plate counts between 30 and 300 colonies per plate (17). Four separate, replicated tests were conducted with disks cut from potato tubers, and one each from carrot and pepper.

\section{RESULTS}

Verification of methodology. Fifty-six of the specimens (28 healthy and 28 soft rotted) were tested for incidence of $\mathrm{H}_{2} \mathrm{~S}^{+}$ colonies by the modified method using only one enrichment broth (selenite cystine) and plating on only one agar (SS), and by the standard method using enrichment in selenite cystine and in tetrathionate broths and plating on HE, XLD, and SS agars. $\mathrm{H}_{2} \mathrm{~S}^{+}$colonies appeared on 25 of the samples enriched in tetrathionate broth and on 21 of the samples enriched in selenite broth. Only 18 of the samples, however, were positive in both broths. Three of the selenite-positive samples were not positive (i.e., confirmed) in tetrathionate broth, while seven of the tetrathionate samples were not confirmed by the selenite broth. Thus, enrichment in selenite cystine broth was considered to be the more conservative procedure of the two. Positive samples

Table 3. Sources of confirmed Salmonella isolates

\begin{tabular}{|c|c|c|c|}
\hline \multirow[b]{2}{*}{ Commodity } & \multicolumn{3}{|c|}{$\begin{array}{l}\text { Confirmed isolates/ } \\
\text { isolates tested }\end{array}$} \\
\hline & $\begin{array}{c}\text { Healthy } \\
\text { tissue }\end{array}$ & $\begin{array}{c}\text { Rotted } \\
\text { tissue }\end{array}$ & $\begin{array}{l}\text { Percent } \\
\text { positive }\end{array}$ \\
\hline Anise & $0 / 1$ & & 0 \\
\hline Broccoli & $\ldots$ & $1 / 2$ & 50 \\
\hline Cantaloupe & $0 / 2$ & & 0 \\
\hline Carrot & $0 / 2$ & $0 / 4$ & 0 \\
\hline Cauliflower & $2 / 2$ & $0 / 1$ & 67 \\
\hline Celery & $3 / 4$ & $1 / 2$ & 67 \\
\hline Cilantro & $1 / 2$ & & 50 \\
\hline Cucumber & $1 / 1$ & $5 / 11$ & 50 \\
\hline Dill & $\ldots$ & $1 / 1$ & 100 \\
\hline Greens, beet & $\ldots$ & $1 / 1$ & 100 \\
\hline Lettuce $^{\mathrm{a}}$ & $2 / 5$ & $0 / 5$ & 20 \\
\hline Mushroom & $0 / 4$ & $1 / 7$ & 9 \\
\hline Parsley & & $0 / 1$ & 0 \\
\hline Pepper $^{b}$ & $2 / 9$ & $7 / 30$ & 23 \\
\hline Potato & $1 / 4$ & $2 / 8$ & 25 \\
\hline Radish & $0 / 2$ & $2 / 6$ & 25 \\
\hline Snap beans & $0 / 5$ & $0 / 3$ & 0 \\
\hline Spinach & $2 / 4$ & $3 / 5$ & 56 \\
\hline Squash & $1 / 2$ & $0 / 5$ & 14 \\
\hline Tomato & $4 / 7$ & $6 / 17$ & 42 \\
\hline Unknown $^{\mathrm{c}}$ & $\ldots$ & $1 / 1$ & 100 \\
\hline Totals & $19 / 56$ & $31 / 110$ & \\
\hline Positive & $33.9 \%$ & $28.1 \%$ & $30.1 \%$ \\
\hline
\end{tabular}

\footnotetext{
a Iceberg and Romaine.

${ }^{\mathrm{b}}$ Bell type and cubanelle.

${ }^{\mathrm{c}}$ Records lost.
}

were positive on all three agars tested, the black colonies being easiest to detect on SS agar.

Of the 42 pure cultures of bacteria tested on SS agar at $37^{\circ} \mathrm{C}$, all Salmonella strains and Proteus vulgaris produced black colonies. The soft rotting bacteria Erwinia and Pseudomonas did not grow or produced black colonies on $\mathrm{SS}$ at $37^{\circ} \mathrm{C}$ within the 48-h incubation period.

Prevalence and concentration of black (hydrogen sulfide-positive) colonies on fruits and vegetables. Forty-eight different types of healthy and soft rotted fruits and vegetables were sampled in the marketplace, each at least five times. Among the healthy specimens, 257 of 781 brothenriched samples (33\%) and 122 of 402 (unenriched) wash samples (30\%) yielded black or black-centered colonies on SS agar (Table 1). By comparison, specimens affected with bacterial soft rot had a higher prevalence of black colonies: 316 of 533 broth-enriched samples (59\%) and 264 of 401 wash samples $(66 \%)$. The pattern of higher prevalence of black colonies on soft rotted than on healthy samples held for almost all commodities tested except for cantaloupe, iceberg lettuce, green onions, cherry, and plum tomatoes, in which differences were not clear. Almost all samples of alfalfa sprouts, bean sprouts, and potatoes had black colonies whether healthy or rotted. Differences between healthy and soft rotted specimens were statistically significant beyond the $99 \%$ level of confidence (paired and unpaired $t$ test values of over 6) for both wash and enriched samples.

Differences between healthy and soft rotted tissues were also demonstrated with 120 pairs of samples, representing 30 different commodities, where soft rotted portions were excised as subsamples and tested against the healthy portions (Table 2). In general, counts were higher in soft rotted samples. Average number of black colonies per milliliter of wash water from the healthy tissues was $1.0 \times 10^{5}$, and from soft rotted tissues was $3.7 \times 10^{6}$, a ratio of 1:37. Average CFU counts per milliliter of enrichment broth were $7.5 \times 10^{7}$ for healthy tissues and $2.7 \times 10^{9}$ for soft rotted tissues, also a ratio of 1:37. Differences were statistically significant beyond the 99\% level of confidence. Correcting CFU values for weight of sample, since healthy portions were generally 10 times the weight of soft rotted portions, average differences increase to 370 times. Variations occurred with cantaloupe, where wash water counts were higher for the healthy rather than the soft rotted portions, and with broccoli, fennel, mushrooms, and russet potatoes, where the same variation occurred with broth-enriched samples. In this particular series of test samples, basil, cabbage, iceberg lettuce, and green onions yielded no black colonies in either healthy or rotted subsamples.
Confirmation test for strains of presumptive Salmonella. Since not all black colonies on SS agar are Salmonella, 166 hydrogen sulfide-positive strains, plus one authentic strain of $S$. typhimurium (ATCC 14028) as a check, were tested for confirmatory physiological and serological reactions. Of the 166 strains, 110 were from soft rotted and 56 from healthy samples. Ninety-one strains were discarded as nonSalmonella by biochemical testing (15). Serological tests on the 75 remaining strains confirmed 50 , or $30.1 \%$ of the 166 , as Salmonella, as well as S. typhimurium ATCC 14028. Thirty-one of 111 strains (28\%) from soft rotted samples and 19 of 55 strains (35\%) from healthy samples were confirmed positive (Table 3 ). The 50 were also positive for Salmonella by the Roche Enterotube tests.

Multiplication of Salmonella on inoculated tissue disks. S. typhimurium multiplied readily at room temperature $\left(21^{\circ} \mathrm{C}\right)$ on inoculated disks of potato, carrot, and pepper in the absence of soft rotting bacteria. From an initial average of less than $10^{6} \mathrm{CFU} / \mathrm{ml}$ (from wash of three inoculated disks), populations peaked in 48 $\mathrm{h}$ at $4.0 \times 10^{8} \mathrm{CFU} / \mathrm{ml}$, as determined by dilutions on PAF agar (Fig. 1A). From determinations on SS agar, Salmonella populations peaked at an average of $1.5 \times$ $10^{7} \mathrm{CFU} / \mathrm{ml}$ (Fig. $1 \mathrm{~B}$ ). No bacteria were detected from water-inoculated controls.

The presence of soft rotting bacteria significantly affected multiplication of Salmonella. On SS agar, $16 \mathrm{~h}$ after inoculation, Salmonella counts averaged more than 10-fold higher in disks coinoculated with Erwinia, and more than fivefold higher in those coinoculated with Pseudomonas. Similarly, as calculated from dilution plating on PAF agar, Salmonella counts $24 \mathrm{~h}$ after inoculation averaged approximately 10-fold higher when coinoculated with Erwinia and threefold higher with Pseudomonas.

\section{DISCUSSION}

Based on this study involving more than 500 samples each of healthy and soft rotted commodities collected in retail markets, the incidence of suspected Salmonella on produce affected by bacterial soft rot was twice that of healthy samples. Concentrations of bacteria were also affected by the presence of bacterial soft rot: there were 37 times more suspected Salmonella in wash from soft rotted samples than from healthy samples. Controlled experiments with tissues inoculated with one strain of Salmonella confirmed that bacterial soft rot infection increased multiplication of Salmonella by at least three- to 10-fold compared with multiplication on uninfected tissues.

The term "suspected Salmonella" has been used throughout to describe black or black-centered bacterial colonies appearing on SS agar incubated 24 to $72 \mathrm{~h}$ at $37^{\circ} \mathrm{C}$. Black colonies from the wash samples 
could be from a variety of $\mathrm{H}_{2} \mathrm{~S}^{+}$bacteria, including Citrobacter, coliforms, Proteus, and Salmonella. Since incubation in selenite cystine broth suppresses coliforms and allows small populations of Salmonella to grow, the likelihood of black colonies being Salmonella was greater in enriched samples. Nevertheless, incidence of black colonies in wash versus enriched samples were comparable, as were incidence ratios between healthy and soft rotted samples. Therefore, unenriched wash samples were a useful indication of possible Salmonella incidence. Confirmatory tests for a random sampling of 166 strains, 111 isolated from (enriched) soft rotted specimens and 55 from healthy samples, and based on key physiological properties and serological reactions, showed 50 of the 166 strains $(30 \%)$ to be Salmonella, 31 from soft rotted and 19 from healthy specimens.

In the few systematic studies in the scientific literature of incidence of Salmonella on fresh fruits and vegetables, percentages have generally been under $10 \%(12,22)$, with the exception of the report by Ercolani (8) in which incidences of 68 and $72 \%$ were reported for leaf lettuce and fennel, respectively. Our percentages, ranging from 30 to $33 \%$ in healthy specimens, refer to incidence of suspected Sal-
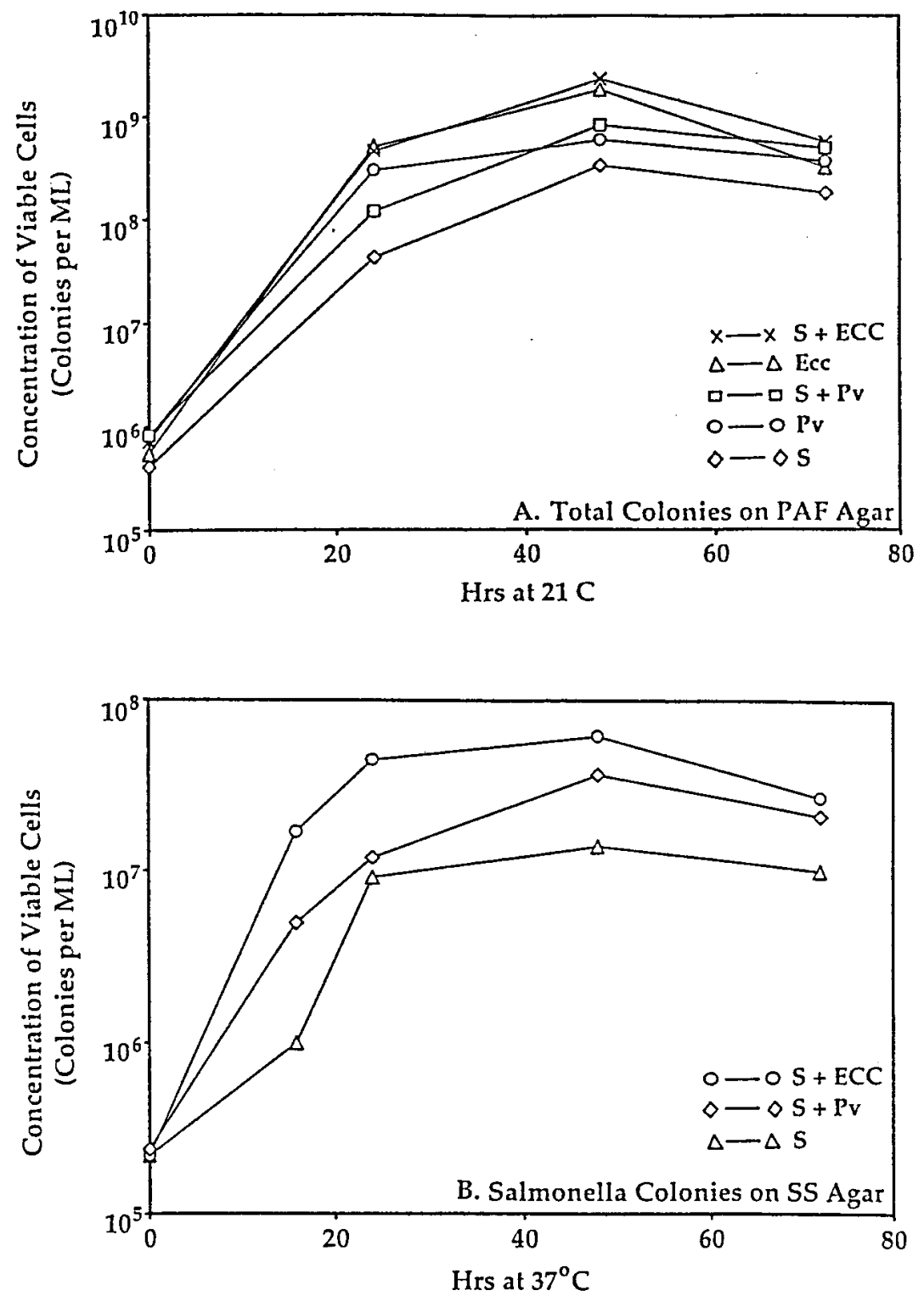

Fig. 1. Concentration of viable cells, determined as $\mathrm{CFU} / \mathrm{ml}$, washed from tissue disks inoculated with $10 \mu \mathrm{l}$ of bacterial suspensions $\left(5 \times 10^{8}\right.$ cells $\left./ \mathrm{ml}\right)$, incubated at $21^{\circ} \mathrm{C}$, and sampled at $0,16,24$, 48 , and $72 \mathrm{~h}$. Three disks per treatment were agitated for $15 \mathrm{~min}$ in $30 \mathrm{ml}$ of sterile water and serially diluted on two different solidified media: top, Pseudomonas Agar F (PAF) (incubated at $21^{\circ} \mathrm{C}$ for 48 h); bottom, Salmonella-Shigella (SS) agar (incubated at $37^{\circ} \mathrm{C}$ for $24 \mathrm{~h}$ ). Dilutions were replicated twice. Inoculation treatments were with Salmonella typhimurium ATCC 14028 (S), Erwinia carotovora E24 (Ecc), Pseudomonas viridiflava $312(\mathrm{Pv})$, Salmonella plus E. carotovora $(\mathrm{S}+\mathrm{Ecc})$, or Salmonella plus $P$. viridiflava $(\mathrm{S}+\mathrm{Pv})$. Each point represents an average of six tests, three disks per test. Potato disks were used with four of the tests, and pepper and carrot disks with one each.

monella strains. Since only $30 \%$ of our suspected strains were confirmed Salmonella, a conservative interpretation would correct incidence values accordingly: 9 to $10 \%$ incidence in healthy samples and 18 to $20 \%$ incidence in soft rotted samples, conforming our data with those of published reports.

Bacterial soft rot on fresh fruits and vegetables, generally considered a sign of poor handling, storage, or sanitation, should also be a warning for possible enteric bacteria. While it can be assumed that Salmonella and other fecal coliforms that may be present in commercially handled fresh produce are at base levels, any factors that favor multiplication of bacteria before consumption could result in a public health problem. Precautions should especially be observed if there is evidence of bacterial decay in foods being prepared. Handling practices that lead to bruising and mechanical damage, the predisposing factors for bacterial soft rot, should be controlled. Finally, since Salmonella survive and grow on contaminated, fresh-cut surfaces of tomatoes $(2,26,28)$ and other vegetables, sanitation and treatments such as chlorination $(20,26)$ should be rigorously practiced in the marketing channels between the packing house and final consumption.

\section{ACKNOWLEDGMENTS}

We gratefully acknowledge the assistance and suggestions of Fredrick J. Angulo, Centers for Disease Control, Atlanta; Jerry A. Bartz, University of Florida, Gainesville; and Kathleen T. Rajkowski, USDA, Philadelphia, in the final preparation of this manuscript.

\section{LITERATURE CITED}

1. Al-Hindawi, N., and Rihab-Rised, M. 1979. Presence and distribution of Salmonella species in some local foods in Baghdad City, Iraq. J. Food Prot. 42:877-880.

2. Asplund, Y., and Nunni, E. 1991. The growth of salmonellae in tomatoes. Int. J. Food Microbiol. 13:177-182.

3. Brenner, D. J. 1984. Family I. Enterobacteriaceae. Pages 408-516 in: Bergey's Manual of Systematic Bacteriology, Vol 1. N. R. Krieg and J. G. Holt, eds. Williams \& Wilkins, Baltimore, MD.

4. Cappellini, R. A., Ceponis, M. J., Wells, J. M., and Lightner, G. W. 1984. Disorders in potato shipments to the New York market, 1972-1980. Plant Dis. 68:1018-1020.

5. Ceponis, M. J., Cappellini, R. A., and Lightner, G. W. 1985. Disorders in crisphead lettuce shipments to the New York market, 1972-1984. Plant Dis. 69:1016-1020.

6. Ceponis, M. J., Cappellini, P. A., and Lightner, G. W. 1986. Disorders in tomato shipments to the New York market, 1972-1984. Plant Dis. 70:261-265.

7. Ceponis, M. J., Cappellini, R. A., and Lightner, G. W. 1987. Disorders in fresh pepper shipments to the New York market, 19721984. Plant Dis. 71:380-382.

8. Ercolani, G. L. 1976. Bacteriological quality assessment of fresh marketed lettuce and fennel. Appl. Environ. Microbiol. 31:847-852.

9. Fairchild, C. 1990. Tomatoes: Salmonella suspect. The Packer, Vol. XCVII, No. 32, Aug. 11, 1990, pp. 1A, 6A.

10. Fairchild, C. 1990. Salmonella outbreak 
source sought. The Packer, Vol. XCVII, No. 33, Aug. 18, 1990, pp. 1A, 7A.

11. Fantasia, M., and Filetici, E. 1994. Salmonella enteritidis in Italy. Int. J. Food Microbiol. 21:7-13.

12. Garcia-Villanova-Ruiz, B., Galvez-Vargas, R., and Garcia-Villanova, R. 1987. Contamination of fresh vegetables during cultivation and marketing. Int. J. Food Microbiol. 4:285-291.

13. Geldreich, E. E., and Bordner, R.-H. 1970. Fecal contamination of fruits and vegetables during cultivation and processing for market. A review. J. Milk Food Technol. 34:184-195.

14. Gould, W. A. 1973. Micro-contamination of horticultural products. HortScience 8:116119.

15. Guthrie, R. K. 1992. Salmonella. CRC Press, Boca Raton, FL.

16. Hedberg, C. W., MacDonald, K. L., and Osterholm, M. T. 1994. Changing epidemiology of food-borne disease: A Minnesota perspective. Clin. Infect. Dis. 18:671-682.

17. Krieg, N. R. 1981. Enrichment and isolation. Pages 112-142 in: Manual of Methods for General Bacteriology. P. Gerhardt, ed. American Society for Microbiology, Washington, DC.

18. Lund, B. M. 1983. Bacterial spoilage. Pages
219-257 in: Postharvest Pathology of Fruits and Vegetables. C. Dennis, ed. Academic Press, London.

19. O'Mahony, P., Cowden, J., Smyth, B., Lynch, D., Hall, M., Rowe, B., Teare, E. L., Tettmar, R. E., Rampling, A. M., Coles, M., Gilbert, R. J., Kingcott, E., and Bartlet, C. L. R. 1990. An outbreak of Salmonella saint-paul infection associated with beansprouts in the UK. Epidemiol. Infect. 104:229-235.

20. Park, D. L., Rua, S. M., Jr., and Acker, R. F. 1991. Direct application of a new hypochlorite sanitizer for reducing bacterial contamination on foods. J. Food Prot. 54:960-965.

21. Poelma, P. L., Andrew, W. H., and Silliker, J. H. 1984. Salmonella. Pages 286-326 in: Compendium of Methods for the Microbiological Examination of Foods. M. L. Speck, ed. American Public Health Association, Washington, DC.

22. Rude, R. A., Jackson, G. L., Bier, J. W., Sawyer, T. K., and Risty, N. G. 1984. Survey of fresh vegetables for nematodes, amoebae and Salmonella. J. Assoc. Official Anal. Chem. 67:613-615.

23. Saddik, M. F., El-Sherbeeny, M. R., and Bryan, F. L. 1985. Microbiological profiles of
Egyptian raw vegetables and salads. J. Food Prot. 48:883-886.

24. Schwartz, S. 1995. Salmonella poisoning: Sprouts are suspect in outbreak. The Packer, Vol. CLL, No. 27, July 3,1995, p. 6A.

25. Snowdon, A. L. 1990. A Color Atlas of PostHarvest Diseases of Fruits and Vegetables. Vol. 2: Vegetables. CRC Press, Boca Raton,

26. Wei, C. I., Huang, T. S., Kim, J. M., Lin, W. F., Tamplin, M. L., and Bartz, J. A. 1995 Growth and survival of Salmonella montevideo on tomatoes and disinfection with chlorinated water. J. Food Prot. 58:829-836.

27. Wood, P. C., Hedberg, C., White, D., et al 1991. A multi-state outbreak of Salmonella javiana infections associated with raw tomatoes. (Abstr.) Page 69 in: CDC Epidemic Intelligence Service 40th Annual Conference, Atlanta, GA. U.S. Department of Health and Human Services, Public Health Service, Washington, DC.

28. Zhuang, R.-Y., Beuchat, L. R., and Angulo, F 1995. Fate of Salmonella montevideo on and in raw tomatoes as affected by temperature and treatment with chlorine. Appl. Environ. Microbiol. 61:2127-2131. 